\title{
SHOULD HYDRAULIC FRACTURING CONTINUE?
}

\author{
Minh Hoang \\ Sam Houston State University; gba_bxm@shsu.edu \\ Balasundram Maniam \\ Sam Houston State University; maniam@shsu.edu \\ Geetha Subramaniam \\ Universiti Teknologi MARA,Selangor,Malaysia: geethamaniam@gmail.com
}

\begin{abstract}
Hydraulic fracturing plays a significant role in the United States oil and natural gas development. Fracturing has not only improved the United States economy but strengthened its national security and created a positive change to the environment. The United States has become the top producer of oil and natural gas, maintaining low natural gas price for U.S. consumers and stabilizing global crude oil prices from the world market. Despite the gains, there are environmental and public health concerns from extracting these valuable natural resources. As a result, there are federal environmental laws and state regulations aiming to protect the public and environment from the hydraulic fracturing process ensuring the United States continued success in producing oil and natural gas.
\end{abstract}

Keywords: Hydraulic Fracturing, Oil and Gas, Shale Gas, Crude Oil

\section{Introduction}

In January 2012 State of Union address, President Obama addressed a blueprint called "An America Built to Last." The blueprint highlighted a commitment to make the most of America's energy resources. The objective was to diminish the United States' dependency on overseas oil by developing all sources of energy in America, especially by increasing domestic oil and natural gas production (Truini, 2009). To achieve this, Obama directed his Administration to ensure the safe development of shale gas.

Shale gas is natural gas that has been enclosed in shale formations, impermeable rock layers, located up to $13,500 \mathrm{ft}$. beneath the earth's surface. Shale gas deposits are different from conventional gas deposits as conventional gas reservoirs are located in pools of permeable rocks typically close to the surface (Joskow, 2013). The shale deposits are formed in various regions of the United States such as the Barnett and Wolfcamp shale deposits in Texas and the Marcellus shale in Pennsylvania. In November 2016, the U.S. Geological Survey estimated that the Wolfcamp shale deposit contained 1.6 billion barrels of liquefied natural gas, 20 billion barrels of oil, and 16 trillion cubic feet of natural gas, the largest deposit ever assessed in the U.S. (United States Geological Survey [USGS], 2016).

Conventional gas reservoirs develop when natural gas in porous reservoirs are trapped by an overlying layer of impermeable rock. Typically, the natural gas will flow to the surface without the use of a pump when a well is drilled into the reservoir. In contrast, shale gas reservoirs are formed in low permeable areas, which prevent the gas from migrating to a more permeable rock region. Thus, shale gas requires a different method to extract the gas (Joskow, 2013).

Hydraulic fracturing also called fracking, is a technique that removes oil and natural gas trapped in shale formations previously considered too difficult or economically unviable. Water, sand and chemicals are pumped into the well to unlock these valuable natural resources. Small fractures or cracks are created in the rock, permitting oil and natural gas to travel into the well from the shale.

The two major drilling techniques used in conjunction with fracking are vertical drilling and horizontal drilling. First, a vertical well is excavated deep in the rock formation. Then horizontal drilling is used to create more access to the trapped gas by exposing the well to more shale deposits. When used in conjunction with horizontal drilling, hydraulic fracturing enables the drilling of shale gas in large quantities (Joskow, 2013). 
The abundance of natural gas from shale production in the U.S. resulted in inexpensive natural gas prices. This is beneficial to the economy, national security and environment. Low cost natural gas benefits industrial, commercial and residential consumers. $\mathrm{T}$ is noted that the total gross domestic product (GDP) from the oil and gas industry has increased over the past few years. Besides, this may result in the U.S. gaining political independence from the Middle East as it increases domestic oil and gas production and become a net exporter of petroleum products. The U.S. will have better leverage against the Middle East and offer greater protection to its allies.

Fuel prices tend to drive the source of fuel use to generate electricity in the U.S.. Hence, the low natural gas price will lead to an increase in natural gas power plants usage while reducing the use of coal power plants. Also, natural gas releases half as much $\mathrm{CO}_{2}$ as coal; thus, reducing the impact on climate changes.

Hydraulic fracturing does not go without controversies. The process for acquiring these natural resources resulted in some risks to the environment. The release of volatile organic compounds (VOC) and greenhouse gases causes air pollution. The huge volume of water consumed during the drilling and fracking process create stress on the surface and ground water supplies. Seismic events have been reported near hydraulic fracturing sites due to the drilling equipment vibration and disposal of wastewater in ponds that eventually seep it way into existing fault lines. Spills and faulty well construction can contaminate underground aquifers and surface water.

Because fracking affects the public health and the environment, there are federal, state and local regulations aiming to protect against these negative consequences. Each state generally regulates the oil and gas industries within their borders. Certain states proceed cautiously with the hydraulic fracturing by engaging in study, while others pass new rules and regulations. The state regulations include well construction standards, permits requirement for fracking, erosion and sediment control plans, well safety plans, and wastewater disposal controls (Bligh \& Wendelbo, 2013). Even though the federal agency does not have the sole responsibility to control the oil and gas industry, the Environmental Protection Agency (EPA) has a range of administration programs that could potentially apply to hydraulic fracturing (Bligh \& Wendelbo, 2013).

This research paper provides a more in-depth analysis of the benefits of hydraulic fracturing to the US. With benefits, there are also tradeoffs for extracting these valuable resources, which this paper will also explore. Finally, this paper will analyze the federal, state and local laws and regulations on the industry.

\section{Literature Review}

The U.S. had approximately two percent of the oil reserves and five percent of the natural gas reserves globally in 2016 (Energy Information Administration [EIA], 2017). Based on latest statistics, the U.S. natural gas production will be approximately 890 billion cubic meters or more than a fifth of global gas produced by 2022 (International Energy Agency [IEA], 2017).In 2017, the Energy Information Administration's annual energy outlook stated that the U.S. natural gas production growth is because of the shale gas development, which will account for almost two-thirds of the natural gas production by 2040 (EIA, 2017). Fig. 1 shows the U.S. projection of natural gas production and net exporter of natural gas through 2040.

These projections indicate that natural gas production will be vital to the US energy independence and economy. Recently, the Business Monitor International (2017) performed a SWOT analysis on the U.S. oil and gas industry and determined that the rapid expansion and production of natural gas from unconventional resources has reduced the country's heavy reliance on energy from foreign markets. The World Economic Forum (2016) concluded, "The enormous economic contribution of the oil and gas industry to many national economies makes its future of critical importance."

Shale gas accounts for approximately twenty-five percent of domestic production and has assisted in keeping natural gas prices reasonably low during the past several years (Joskow, 2013). Natural gas continues to grow at a low price in the U.S. from the abundant unconventional natural gas resources according to a study conducted by MIT (2011). The Henry Hub average natural gas spot price in August 2017 was $\$ 2.90$ per million British thermal units (MMBtu). The EIA forecasts Henry Hub natural gas price to rise modestly, from $\$ 3.05$ per MMBtu in 2017 to $\$ 3.29$ per MMBtu in 2018, because of expected growth in exporting natural gas and domestic consumption (EIA, 2017). 

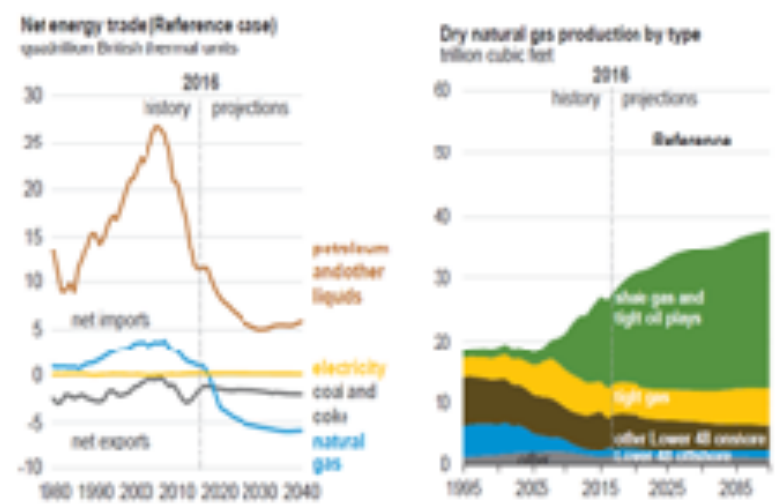

Figure 1. U.S. net natural gas exporter (left) and breakdown of natural gas production (right). Source: EIA Annual Energy Outlook 2017.

Fig. 2 shows the EIA annual outlook for 2017 which projects an increase in natural gas consumed by the industrial and electric power markets in the U.S.. Increase in natural gas usage is beneficial to the environment as well. The MIT (2011) study revealed that the abundance of domestic natural gas usage in the electric generation industry played a major role in decreasing U.S. carbon dioxide emissions by as much as $50 \%$, as increasing gas power generation replaced coal power generation. Natural gas provides a cost-effective bridge for $\mathrm{CO} 2$ emission reduction. Farquharson et al. (2016) compared climate change with the use of electric generation with coal versus natural gas operation for 20 and 100 years and concluded that using natural gas as an alternative to coal for power generation diminishes the climate change.

Hydraulic fracturing brings a great deal of benefits to the U.S., but there are many risks and negative effects associated with extracting the shale gas. These risks include air emission, increase water usage, seismic activity, and water contamination. Mason, Muehlenbachs, and Olmstead (2014) discussed the pollution to the environment from the shale gas wastewater flowing to rivers and streams and methane gas migrating to drinking water wells. In Europe, the European Parliament (2011) conducted a study of unconventional gas activities in North America on environmental impacts and identified air pollutant emission, soil and water contamination, large amounts of water consumption, and methane leaks into groundwater occurring during the hydraulic fracturing process. 


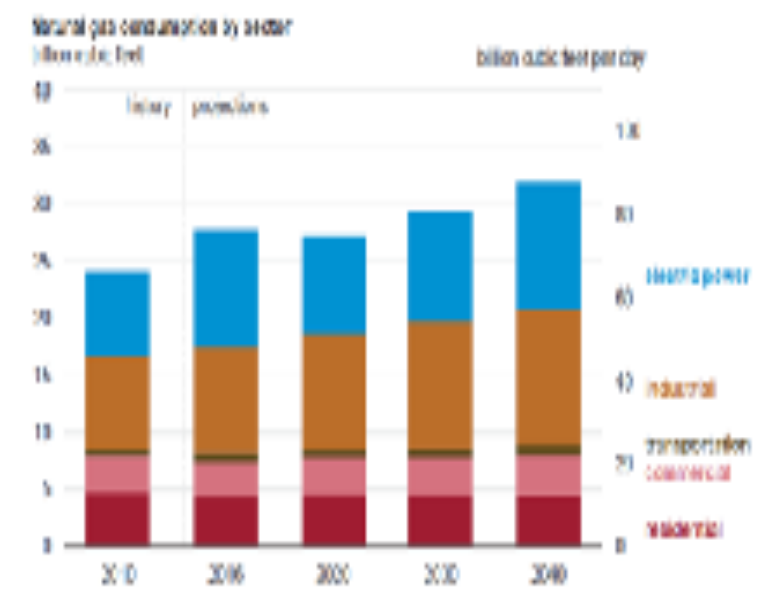

Figure 2: Increase domestic natural gas from the industrial and electric power markets.

Source: EIA Annual Energy Outlook 2017

Due to the potential environmental impacts, Bligh and Wendelbo (2013) discussed the needs for a regulatory framework at the federal and states level to deal with the rapid shale gas development. Bishop, Lampe, Okey, Wilber, and Arnowitt (2012) emphasized that priorities must be given to human health and the environment. According to Negro (2012), the federal environment law, Safe Drinking Water Act, does not include fracking unless diesel fuel is used in the fracking process. The Clean Water Act requires a permit to discharge any toxic chemicals into the United States' waters, which can extend to the wastewater disposal from hydraulic fracturing. Under the Clean Air Act, the EPA can enforce air emission standards from all sources including fracking operations. The Resource Conservation and Recovery Act govern the disposal of solid waste, which hydraulic fracturing can fall under. This research begins by taking a closer look at the benefits that hydraulic fracking brings to the U.S.

\section{Benefits to the United States}

The significant amount of oil and natural gas production has had a profound impact on the economy, resulting in increased employment opportunities and contribution to the GDP. As the US uses more natural gas than coal, there will be a reduction of greenhouse gas release into the atmosphere and a slowdown in global warming. Finally, fracking allows the U.S. to tap into some of the largest oil and gas reserves; therefore, the country will rely less on foreign countries for these fossil fuel.

\section{Environmental Benefits}

The abundance natural gas contributes significantly to the well-being of the environment. Coal pollutes the air by introducing particulate matter, carbon monoxide, and Sulphur dioxide. Natural gas burns much cleaner than coal. Almost half of the electricity produced in the US comes from power plants that use coal. US greenhouse gas emissions can further be reduced by using mostly natural gas to generate electricity. The recent decline in natural gas prices has resulted in power plants switching to natural gas. Fig 3 shows that the electricity generated from coal power plants has declined from $45 \%$ in 2010 to $30 \%$ in 2016 and this trend is projected to continue whereas natural gas usage has surged from $24 \%$ in 2010 to $34 \%$ in 2016 (EIA, 2017). 


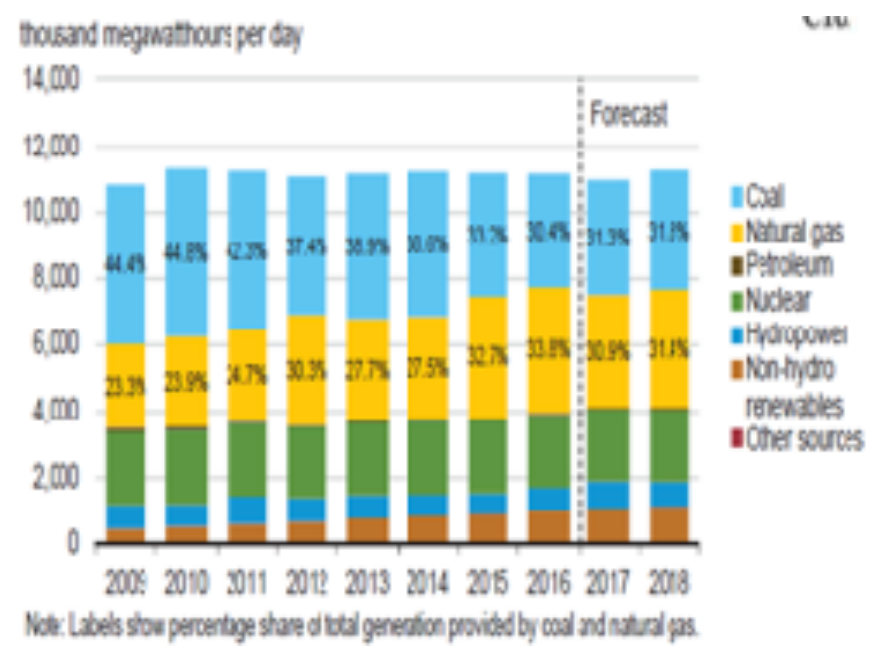

Figure 3. Various U.S. electricity generation sources Source: EIA (2017)

To combat climate change, the amount of carbon dioxide emissions must be reduced. The emission of carbon dioxide from burning natural gas is half as much as burning coal (National Energy Technology Laboratory, 2013). The U.S. carbon dioxide emissions were reduced by $12 \%$ from 2005 to 2012 by substituting coal with natural gas (EIA, 2016). This reduction was the largest in the world and happened at a time when global emissions went up by $8 \%$ (Farquharson et al., 2017). In comparison, China and Europe made less progress on reducing carbon dioxide emissions since coal is still the predominant source of fuel because natural gas is more expensive in these countries.

More progress can still be made by adopting natural gas for home heating and transportation. In the short term, fracturing facilitates the use of natural gas to reduce greenhouse gases while allowing renewable energy technologies such as wind, solar and geothermal to further develop in the long term. Moreover, the risk of a nuclear power plant accident such as Chernobyl, Three Mile Island and Fukushima can be avoided by using more natural gas power plants.

\section{National Security through Energy Independence}

The world's leader in oil and natural gas exporters are located in regions that are either hostile or unstable to the US. Therefore, there are geopolitical advantages to reducing the US dependencies on imported oil and natural gas from these nations. Some of the top oil exporting countries are Saudi Arabia, Russia, Iran, Iraq, Qatar, Norway, and UAE (CIA, 2017). Seventy percent of the world's gas reserves reside in Iran, Qatar, Russia, and Saudi Arabia (CIA, 2017). A few of these nations seek to undermine the US foreign policy objectives and with the oil and natural gas revenue generated will support their capability. In addition, the revenue generated from the oil and gas in the hostile nations may fund terrorist cells that target the U.S. and its allies. The Middle East has become more unstable and hostile to the US as evidenced by the $9 / 11$ terrorist attack, the attack on the U.S. Consulate in Benghazi and the killing of American troops. 
Fortunately, the US has been reducing the volume of imported crude oil. In 2005, the US imported $60 \%$ of its oil which dropped to $36 \%$ in 2013 . For the first time in 2011, the US became a net petroleum exporter with 890 million barrels imported and 913 million barrels exported (Dixon \& Panico, 2013). According to the IEA, the US is projected to be $97 \%$ energy self-sufficient by 2035 (IEA, 2014). In addition, the US is becoming a supplier of crude and fuel to Latin America, Europe and Asia. If Europe begins to buy natural gas from the US and rely less on gas from Russia, Russia will have less leverage over Europe and the US allies.

The US spends billions of dollars each year to police the sea-lanes from the Middle East such as the Strait of Hormuz. However, as the US imports less oil, the spending to protect the sea-lanes for the US interest will eventually decrease. The decreased spending in these areas will allow the US to better allocate the defense budget to other sectors where resources are needed most.

It is an obvious advantage to become energy independent, so the US can have a better advantage on foreign policy in the Middle East. In the past, the President of the US championed this goal and with the reserve in the US shale, this goal is attainable. In March 2017, President Trump signed an executive order on supporting US energy independence to ensure the Nation geopolitical security (Office of the Press Secretary, 2017).

\section{Environmental Issues}

Despite the advantages from hydraulic fracturing, the method of extraction remains highly controversial due to the potential danger it causes to the public safety and environment. There have been reports of air pollution, large volume of water usage, seismic events and aquifer contamination associated with fracking activities.

\section{Air Pollution}

Air pollution is an environmental risk that occurs from the drilling of shale bed, which arises in several ways. Methane, which contributes to greenhouse gas emission, may be released from wells or leaky pipelines. In addition, methane can cause explosions. One of the fluid use in fracturing is benzene, a volatile organic compound (VOC). When the fluid evaporates, it can be released to into the atmosphere (Twomey, Farias, \& Harris, 2016). VOC can increase the risk of cancer, as well as nausea, stroke, heart attack, asthma, and birth issue (Twomey, Farias, \& Harris, 2016). As a result, some states, such as Texas, monitor VOC emissions at drilling sites while other states such as Colorado require the use of vapor recovery systems or holding tanks to reduce VOC emissions. The EPA new regulation aims at reducing VOC emissions from oil and gas industry by $25 \%$ (EPA, 2016). The fracturing process involves drilling deep under the earth where naturally occurring radioactive isotopes are located. The drilling process can potentially bring these radioactive isotopes to the surface. Any amount of radiation expose can increase the risk of cancer. Finally, the drilling equipment and vehicles such as trucks and bulldozer used at the drilling site emit large amounts of air pollution.

\section{Water Usage}

Fracturing requires a large amount of water, which can be drawn from rivers, ponds, lakes, or aquifers. Each well uses between 2 to 7 million gallons that are injected into the well (Entrekin, Evans-White, Johnson, \& Hagenbuch, 2011). A well pad contains several wells that further compound water usage. The EPA assesses that fracturing will require an equivalent water usage as high as five million people when 35,000 wells are fracked per year (Bligh \& Wendelbo, 2013). Depending on the local water supply inventory, the significant amount of water usage can affect the water supply where the wells are drilled. Shale gas drilling water usage is not different from other economic activities. For example, in Texas, irrigation uses $56 \%$ of the state's annual water consumption, municipal use is $26 \%$, and shale gas use is less than $1 \%$ (Wicot, 2012). Livestock uses more water than shale gas drilling in all states. In addition, shale gas drilling uses less water per unit of energy than other forms of energy and is equivalent to coal (Wicot, 2012).

In some areas, about 20-40 percent of the injected fluid volume flow back to the surface is captured and reused (Bishop, Lampe, Okey, Wilber, \& Arnowitt, 2012). The benefit of recycling this water is not only decrease the volume of water required for fracturing but reduces the inventory of fracturing waste that needs to be disposed.

\section{Earthquakes and Tremors}

Minor earthquakes and tremors have been reported in cities where fracturing activities occur. The vibration from drilling as well as waste water injection have been connected to earthquakes (Twomey, 
Farias, \& Harris, 2016). The National Research Council determines that hydraulic fracturing does not necessary correlate to seismic events.

The disposal of fracking fluid into the wastewater ponds have been link to earthquakes. The injected fluid "greases" the fault for a long period of time. A series of earthquake in Denver were linked to the wastewater disposal in the 1960s (Ehrenberg, 2012).

\section{Water Contamination}

Fracturing can lead to the risk of contaminating surface and underground water. During and after fracturing, the fractured fluid may seep from the shale seam into groundwater and aquifers. Fracturing fluid consists of $99.5 \%$ water and sand and $0.5 \%$ toxic chemicals (Fischetti, 2010). Advances in technology may help reduce the amount of lethal chemical use in shale oil and gas drilling, but leaks and spills can still occur during the drilling process.

The fracturing process develops cracks in underground shale formations so that gas and oil can migrate through. However, the risk is remote according to geologist since fracturing in shale deposits occur between 6,000 to 10,000 feet, whereas the water table typically locates at 600 to 1,000 feet below the earth's surface (MIT, 2011).

Finally, there is a risk of blowout, an uncontrolled release of gas or fluid gushing out of the well due to unexpected level of pressure. Between 2012 and 2013, 897 water contamination problems were found (Towmey, Farias, \& Harris, 2016)

\section{Laws and Regulations}

Due to the environmental concern and human safety implication, federal and state agencies share the responsibility for regulating the oil and gas industry from hydraulic fracturing. Greater oversights at the federal and state level ensure the U.S. will reap the benefits from acquiring the abundance natural resources without harmful effects on the public health and environment.

\section{Federal Regulation}

There is not a complete federal regulatory for fracturing. Hydraulic fracturing regulation has traditionally been handled at the state function. However, environmental regulation is governed by the EPA. The Clean Water Act and Clean Air Act require permits and compliance with federal standards for air and water emission. The Resource Conservation and Recovery Act governs major hazardous waste. The Safe Drinking Water Act establishes federal drinking water protection standards, which fracturing operations are exempt. In addition, there is no federal law that requires the disclosure of chemical composition of fracturing fluid to the EPA. Thus, the fact that fracking operations enjoy certain exemptions from some of these federal requirements has intensified fears surrounding those operations (Bligh \& Wendelbo, 2013).

\section{State Regulation}

Since there are not any complete federal regulations for hydraulic fracturing and laws to address the public concerns over fracturing activities, the state and local governments have assumed the primary role in governing these processes. To enforce the rules, state regulations carry competing interest. On one end, lawmakers want to ensure the safety of the environment and health and well-being of its citizens. On the other end, the oil and natural gas production play an important role in tax revenue and income for the states. Therefore, states have approached differently to deal with these conflicting interests (Bligh \& Wendelbo, 2013).

The state regulations for fracturing focused primarily on the following: 1) chemical and additives used in fracturing need to be disclosed, 2) water quality need to be protected and monitored, 3) spill and leak need to be mitigated, 4) storage, treatment, disposal, and transport of waste and harmful waste, 5) restriction in wells location, and 6) economic impact connected with fracturing (Bligh \& Wendelbo, 2013).

States with large volume of oil and natural gas deposits depend greatly on the income to pay for different programs such as school. The oil and natural gas industry provide thousands of jobs, which generate significant amount of revenues for the states. Not surprisingly, states such as Florida and Alaska do not have an existing regulations or legislations to govern hydraulic fracturing (Bligh \& Wendelbo, 2013).

However, certain states have a strong legislative framework governing fracturing such as Pennsylvania, Texas, and West Virginia. 


\section{Trump's Strong Support for Drilling}

The new administration of President Donald J. Trump is positive news for the U.S. oil and gas industry. During his campaign, President Trump made numerous promise to increase the US oil and gas production and withdraw hindering regulations. Former President Obama's policies were to promote environmental regulation, renewable energy, and climate change (Bezdek, 2017). President Trump's policies differ from Obama.

In his cabinet, President Trump has selected former Texas Governor Rick Perry to head the Energy Department and former Exxon Mobil CEO Rex Tillerson as Secretary of States. Rick Perry and Tex Tillerson are staunch supporter of unconventional gas development (Business Monitor International, 2017). These appointees indicate that President Trump is committed at removing Obama's energy and environmental regulation and prioritized fossil fuel development. Since taking office, President Trump has signed executive order to allow the extraction of oil and natural gas off the U.S. Arctic and Atlantic coasts (MarketLine Industry Profile, 2017).

\section{Conclusion}

Hydraulic fracturing has had a profound impact on the U.S.' economy. Total GDP from the oil and natural gas industry has increased to hundreds of billion dollars over the years and the trend continues. The lower natural gas prices have resulted in more electricity generation to switch to natural gas as the source of fuel. Increased use of gas power plants has facilitated a reduction of coal power plants. Reduction in coal usage has reduced carbon dioxide emission and slowed down global warming. The fracking revolution has led the U.S. to turn into an exporter of petroleum products; thus, reducing the Nation's energy dependence from the Middle East, while at the same time improve national security.

Fracking does come with the cost to the environment. However, improved technology and stricter regulations can mitigate the environmental risk. The use of natural gas instead of diesel fuel on the drilling machineries and vehicles can help mitigate the emission problems. New equipment can help minimize water usage and recycling the wastewater can further reduce the contaminated water disposal. Possible solution to prevent seismic activities due to wastewater seepage through existing fault line includes providing wastewater pond with liner to stop the water from leaking into the ground.

As with any activities, there are legal and regulation frameworks to ensure the health and safety of the public and environment. The federal government should continue to allow the states to regulate hydraulic fracturing activities. The states are in a better position to understand the cost and benefits of fracking and its citizen needs. Although the federal government has few fracking regulations, the federal government should have a minimum safety standard since problems that affect climate change affect the entire nation.

It is obvious that President Trump is a strong supporter of drilling of America's oil and natural gas. President Trump rescinds former President Obama environmental regulation and climate change; therefore, allowing hydraulic fracturing to extract unconventional oil and natural gas resources. President Trump's strong support for hydraulic fracturing will make the oil and gas industry grow again at the displeasure of the envornmentalists.

\section{References}

Bezdek, R. H. (2017). A new day dawns in d.c. for the u.s. e\&p industry. World Oil, 238(2), 37-40.

Bishop, R., Lampe, D., Okey, B., Wilber, T., \& Arnowitt, M. (2012). "Fracking:" a roundtable. Journal of Appalachian Studies, 18(1/2), 31-47.

Bligh, S., \& Wendelbo, C. (2013). Hydraulic Fracturing: Drilling Into the Issue. Natural Resources \& Environment, 27(3), 7-12.

Bureau of Economic Analysis. (2017). Industry Gross Domestic Products. Retrieved from https://

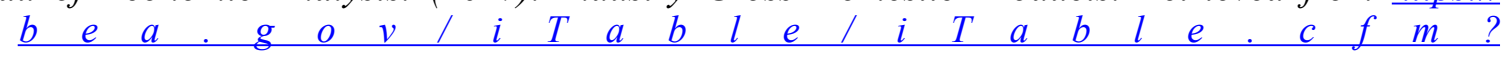
$\underline{\text { reqid }}=51 \&$ step $=51 \&$ isuri $=1 \& 5114=a \& 5102=1$ \#reqid $=51 \&$ step $=51 \&$ isuri $=1 \& 5114=a \& 5102$ $=1$

Business Monitor International Research (2017). United States Oil and Gas report Q3 2017. Business Monitor International.

Central Intelligence Agency (2017). The World Factbook. Retrieved from

https://www.cia.gov/library/publications/the-world-factbook/rankorder/2242rank.html

Dixon, S., \& Panico, J. (2013). Extraction for exportation: is there such a thing as "net energy independence"?. Natural Resources \& Environment, 27(3), 38-42. 
Ehrenberg, R. (2012). The facts behind the frack: scientists weigh in on the hydraulic fracturing debate. Science News, 182(5), 20-25.

EIA (2017), Energy Information Administration short-term energy outlook 2017.Retrieved from https:// www.eia.gov/outlooks/steol

Entrekin, S., Evans-White, M., Johnson, B., \& Hagenbuch, E. (2011). Rapid expansion of natural gas development poses a threat to surface waters. Frontiers in Ecology and the Environment, 9(9), 503-511.

European Parliament. (2011). Impact of shale gas and shale oil extraction on the environment and on human health. Brussels: European Parliament.

Farquharson, D., Jaramillo, P., Schivley, G., Klima, K., Carlson, D., \& Samaras, C. (2017). Beyond global warming potential: a comparative application of climate impact metrics for the life cycle assessment of coal and natural gas based electricity. Journal of Industrial Ecology, 21(4), 857-873.

Fischetti, M. (2010). The drillers are coming. Scientific American, 303(1), 82-85.

IHS Global Insight (2013, September 4). U.S. Unconventional Oil and Gas Revolution to Increase Disposable Income by More than \$2,700 per Household and Boost U.S. Trade Position by More than $\$ 164$ billion in 2020. Retrieved from

http://news.ihsmarkit.com/press-releaseleconomics/us-unconventional-oil-and-gas-revolutionincrease-disposable-income-more-270

International Energy Agency (2017, July 13). IEA sees global gas demand on the rise until at least 2022. Retrieved from

https://www.iea.org/newsroom/news/2017/july/iea-sees-global-gas-demand-rising-to-2022-as-usdrives-market-transformation.html

International Energy Agency (2012). World Energy Outlook 2012

Joskow, P. (2013). Natural gas: from shortages to abundance in the united states. The American Economic Review, 103(3), 338-343.

MarketLine Industry Profile (2017). Oil \& Gas in the United States-September 2017.

Mason, C.F., Muehlenbache, L.A., \& and Olmstead, S.M. (2014). The economics of shale development.

MIT Study. (2011). The future of natural gas. An Interdisciplinary MIT Study.

National Energy Technology Laboratory. (2013). Cost and Performance Baseline for Fossil Energy Plants.

Negro, S. E. (2012). Fracking wars: federal, state and local conflicts over the regulation of natural gas activities. Zone and Planning Law Report, 2, 1-16.

Office of the Press Secretary. (2017, March 28). Presidential Executive Order on Promoting Energy Independence and Economic Growth. Retrieved from https://www. whitehouse.gov/the-press-office/2017/03/28/presidential-executive-orderpromoting-energy-independence-and-economi-1

President Barack Obama. (2012, January 24). 2012 State of the Union Address. Retrieved from https://obamawhitehouse.archives.gov/the-press-office/2012/01/24/remarks-president-stateunion-address

Twomey, D. F., Twomey, R. F., Farias, C., Farias, G., \& Harris, D. L. (2016). Fracking: blasting the bedrock of business. Journal of Competitiveness Studies, 24(3), 107-127

U.S. Energy Information Administration. (2017). Annual Energy Outlook 2017.

U.S. Energy Information Administration. (2017). Short Term Energy Outlook-September 2017.

U.S. Energy Information Administration. 2016 https://www.eia.gov/todayinenergy/detail.php? $\underline{i d}=26152$

U.S. Environmental Protection Agency (2016, May 12). https://www.epa.gov/newsreleases/epareleases-first-ever-standards-cut-methane-emissions-oil-and-gas-sector

United States Geological Survey. (2016, November 15). https://www.usgs.gov/news/usgs-estimates-20billion-barrels-oil-texas-wolfcamp-shale-formation 